\title{
PELATIHAN MP-ASI PANGAN BERBASIS LOKAL DALAM PENINGKATAN PENGETAHUAN IBU DAN STATUS GIZI PADA ANAK DIBAWAH DUA TAHUN DI WILAYAH PUSKESMAS KABUPATEN MINAHASA TENGGARA
}

\author{
Nita R. Momongan ${ }^{1, a)}$, Olfie Sahelangi ${ }^{2, a)}$ \\ 1Jurusan Gizi Poltekkes Kemenkes Manado Indonesia \\ aPUI Poltekkes Kemenkes Manado \\ email korespondensi: nitarianymomongan@gmail.com
}

\begin{abstract}
ABSTRAK
Appropriate supplementary food breast milk should start at 6 months of age, but the reality in many infants under 6 months has been given food. According to data Riskesdas 2013, North Sulawesi Province of malnourished status of 3.7\% (National $5.7 \%$ ) and nutritional status less $12.8 \%$ (National 13.9\%). Results of Nutrition Status Monitoring (2015) North Sulawesi Province, nutrition sufferer less $10.6 \%$, for stunting case with very short category North Sulawesi Province 6.3\%, and short category $15 . \%$. The purpose of this research is to know mother knowledge and nutritional status of children under two yearsbefore and after getting training of local food-based supplementary food breast milk in South Minahasa Regency.

The research type is quasi experiment with pre and post design control group design. This study was conducted in the area of Puskesmas district South Minahasa in June to September 2017. The population in this study were all mothers with children aged 12 to 24 months. Total sample amounted to 70 samples consisted of treatment group 35 samples and control group 35 samples and how to determine the sample size by Simple random sampling. Bivariate analysis used different test of two groups in pairs and inter-group different test.

Result of research and conclusion: There is significant difference of knowledge of Baduta mother before and after training of local food-based supplementary food breast milk. There was no significant difference in nutritional status of Baduta children before and after local food-based supplementary food breast milk.
\end{abstract}

Keywords: Supplementary food breast milk Training; Local food, Mother's Knowledge; Nutritional status

\section{PENDAHULUAN}

Pemberian MP-ASI yang tepat sebaiknya di mulai saat usia bayi 6 bulan , namun kenyataan dimasyarakat banyak bayi yag beruasi dibawah 6 bulan sudah diberi makanan. Sejak tahun 2006, World Health Organization (WHO) mencatat jumlah ibu yang memberikan MP-ASI di bawah 2 bulan mencakup $40 \%$ dari total bayi yang ada, $46 \%$ pada bayi usia 2-3 bulan dan $14 \%$ pada bayi usia 6 bulan. Pemberian MP-ASI pada bayi $6 \mathrm{~s} / \mathrm{d} 24$ bulan dimaksudkan agar kebutuhan bayi dapat terpenuhi (selain pemberian Air Susu Ibu), asupan gizi yang baik akan membantu bayi dalam pertumbuhan dan perkembangannya menjadi lebih optimal. Karena itu persyaratan 
yang dimiliki oleh MP-ASI adalah nilai gizi dan kandungan proteinnya tinggi, memiliki nilai suplementasi yang baik, mengandung vitamin dan mineral dalam jumlah yang cukup, dapat diterima dengan baik dan sebaiknya diproduksi dari hasil bahan-bahan pangan lokal. Data Riskesdas 2013, Provinsi Sulawesi Utara penderita status gizi buruk 3,7\% (Nasional 5.7\%) dan status gizi kurang $12.8 \%$ (Nasional 13.9\%). Hasil Pemantauan Status Gizi (PSG 2015) Provinsi Sulawesi Utara, penderita gizi kurang $10.6 \%$ dan Kabupaten Minahasa Tenggara8.3\%, untuk kasus stunting dengan kategori sangat pendek Provinsi Sulawesi Utara 6.3\% (Kabupaten Minahasa Tenggara8.8 \%), dan kategori pendek 15.\% (Kabupaten Minahasa Tenggara13.3\%).

Faktor pemenuhan zat gizi memegang peranan penting dalam siklus hidup manusia. Kekurangan zat gizi pada ibu hamil dapat menyebabkan Bayi Berat Lahir Rendah (BBLR) dan dapat pula menyebabkan penurunan tingkat kecerdasan. Pada bayi dan anak, kekurangan gizi akan menimbulkan gangguan pertumbuhan dan perkembangan yang apabila tidak diatasi secara dini dapat berlanjut hingga dewasa. Usia 0-24 bulan merupakan masa pertumbuhan dan perkembangan yang pesat, sehingga kerap diistilahkan sebagai periode emas sekaligus periode kritis. Periode emas dapat diwujudkan apabila pada masa ini bayi dan anak memperoleh asupan gizi yang sesuai untuk tumbuh kembang optimal. Sebaliknya apabila bayi dan anak pada masa ini tidak memperoleh makanan sesuai kebutuhan gizinya, maka periode emas akan berubah menjadi periode kritis yang akan mengganggu tumbuh kembang bayi dan anak, baik pada saat ini maupun masa selanjutnya.

Untuk mencapai tumbuh kembang optimal, di dalam Global Strategy for Infant and Young Child Feeding, WHO/UNICEF merekomendasikan empat hal penting yang harus dilakukan yaitu; pertama memberikan Air Susu Ibu kepada bayi segera dalam waktu 30 menit setelah bayi lahir, kedua memberikan hanya Air Susu Ibu (ASI) saja atau pemberian ASI secara eksklusif sejak lahir sampai bayi berusia 6 bulan, ketiga memberikan Makanan Pendamping Asi (MP-ASI) sejak bayi berusia 6 bulan sampai 24 bulan, dan keempat meneruskan pemberian ASI sampai anak berusia 24 bulan atau lebih. Rekomendasi tersebut menekankan, secara sosial budaya MP-ASI hendaknya dibuat dari bahan pangan yang murah dan mudah diperoleh di daerah setempat (indigenous food).

Hasil penelitian yang dilakukan oleh peneliti tahun 2016 menunjukkan bahwa pelatihan kepada ibu anak Baduta tentang MP-ASI lokal di Wilayah Puskesmas Likupang Barat Kabupaten Minahasa Utara dapat meningkatkan pengetahuan, asupan zat gizi anak serta status gizi anak. Berdasarkan latar belakang tersebut, peneliti akan melanjutkan dengan memberikan pelatihan kepada kader gizi sehingga dapat ditransfer ke ibu-ibu yang mempunyai anak Baduta di lokasi dan metode yang berbeda. Tujuan Penelitian ini yaitu untuk mengetahui pengetahuan ibu dan status gizi anak baduta sebelum dan sesudah mendapatkan pelatihan pembuatan MP-ASI berbasis pangan local di Kabupaten Minahasa Tenggara. Manfaat Peneltian untuk membantu menambah pengetahuan ibu baduta dan meningkatkan status gizi anak baduta serta dapat mempromosikan bahan pangan lokal sebagai MP-ASI

\section{METODE}

Jenis penelitian adalah quasi eksperimen dengan rancangan pre and post tes control group desain. Penelitian ini dilaksanakan di wilayah Puskesmas Kabupaten Minahasa Tenggara pada bulan Juni sampai bulan September 2017. Populasi dalam penelitian ini adalah seluruh ibu yang mempunyai anak usia 12 sampai 24 bulan. 
Total sampel berjumlah 70 sampel terdiri kelompok perlakuan 35 sampel dan kelompok kontrol 35 sampel dan cara penentuan besar sampel dengan cara Simple random sampling. Analisis bivariat menggunakan uji beda dua kelompok berpasangan dan uji beda antar kelompok. Analisis dan interpretasi data selanjutnya disajikan dalam bentuk table, diagram dan pembahasan dan selanjutnya dilakukan analisis bivariat menggunakan uji beda (Uji T dua kelompok berpasangan untuk mengetahui perbedaan sebelum dan sesudah intervensi)

\section{HASIL DAN PEMBAHASAN}

\section{Pengetahuan Ibu Tentang Gizi}

\section{Pengetahuan Ibu Sebelum Intervensi Kelompok Perlakuan}

Tingkat pengetahuan ibu sebelum diberikan intervensi pada kelompok perlakuan dapat dilihat pada Tabel 1 berikut ini.

Tabel 1. Distribusi Responden Menurut Tingkat Pengetahuan Ibu Sebelum Intervensi Pada Kelompok Perlakuan

\begin{tabular}{llcc}
\hline & Pengetahuan Ibu & \multicolumn{2}{c}{ Jumlah } \\
\cline { 3 - 4 } No & Baik $>80 \%$ & 31 & $\%$ \\
\hline 1 & Sedang 60-79.9\% & 4 & 89 \\
2 & Jumlah & 35 & 11 \\
\hline
\end{tabular}

Berdasarkan hasil pada Tabel 1, tingkat pengetahuan ibu sebelum intervensi pada kelompok perlakuan hanya berpengetahuan baik yaitu 31 orang (89\%) dan sedang berjumlah 4 orang (11\%).

\section{A. Pengetahuan Ibu Sebelum Intervensi Kelompok Kontrol}

Pengetahuan ibu sebelum intervensi pada kelompok kontrol lebih jelasnya dapat dilihat pada Tabel 2 berikut ini.

Tabel 2. Distribusi Responden Menurut Pengetahuan Ibu Sebelum Intervensi Pada Kelompok Kontrol

\begin{tabular}{llll}
\hline \multirow{2}{*}{ No } & Pengetahuan lbu & \multicolumn{2}{c}{ Jumlah } \\
\cline { 3 - 4 } & & $\mathrm{n}$ & $\%$ \\
\hline 1 & Baik $>80 \%$ & 22 & 63 \\
2 & Sedang $60-79.9 \%$ & 13 & 37 \\
\hline Jumlah & 35 & 100 \\
\hline
\end{tabular}

Berdasarkan hasil pada Tabel 2, tingkat pengetahuan ibu sebelum intervensi pada kelompok kontrol hanya berpengetahuan baik yaitu 22 orang $(63 \%)$ dan sedang berjumlah 13 orang (37\%).

\section{B. Pengetahuan Ibu Sesudah Intervensi Kelompok Perlakuan}

Tingkat pengetahuan ibu sesudah diberikan intervensi pada kelompok perlakuan dapat dilihat pada Tabel 3 berikut ini. 
Tabel 3. Distribusi Responden Menurut Tingkat Pengetahuan Ibu Setelah Intervensi Pada Kelompok Perlakuan

\begin{tabular}{llcc}
\hline \multirow{2}{*}{ No } & Pengetahuan lbu & \multicolumn{2}{c}{ Jumlah } \\
\cline { 3 - 4 } & & $\mathrm{n}$ & $\%$ \\
\hline 1 & Baik $>80 \%$ & 35 & 100 \\
2 & Sedang 60-79.9\% & 00 & 0 \\
\hline Jumlah & 35 & 100 \\
\hline
\end{tabular}

Berdasarkan hasil pada Tabel 3, tingkat pengetahuan ibu setelah intervensi pada kelompok perlakuan semuanya berpengetahuan baik yaitu 35 orang (100\%).

Pengetahuan Ibu Sesudah Intervensi Kelompok Kontrol

Pengetahuan ibu setelah intervensi pada kelompok kontrol lebih jelasnya dapat dilihat pada Tabel 4 berikut ini,

Tabel 4. Distribusi Responden Menurut Pengetahuan Ibu Setelah Intervensi Pada Kelompok Kontrol

\begin{tabular}{llcc}
\hline \multirow{2}{*}{ No } & \multirow{2}{*}{ Pengetahuan lbu } & \multicolumn{2}{c}{ Jumlah } \\
\cline { 3 - 4 } & & $\mathrm{n}$ & $\%$ \\
\hline 1 & Baik $>80 \%$ & 24 & 69 \\
2 & Sedang $60-79.9 \%$ & 11 & 33 \\
\hline Jumlah & 35 & 100 \\
\hline
\end{tabular}

Berdasarkan hasil pada Tabel 4, tingkat pengetahuan ibu setelah intervensi pada kelompok kontrol berpengetahuan baik yaitu 24 orang $(69 \%)$ dan sedang berjumlah 13 orang (37\%).

\section{Status Gizi Baduta}

\section{Status Gizi Baduta Sebelum Intervensi Pada Kelompok Perlakuan}

Status gizi anak Baduta sebelum intervensi kelompok perlakuan lebih jelasnya dapat dilihat pada Tabel 5 berikut ini.

Tabel 5. Distribusi Responden Menurut Status Gizi (BB/U) Sebelum Intervensi Pada Kelompok Perlakuan

\begin{tabular}{llcc}
\hline \multirow{2}{*}{ No } & \multirow{2}{*}{ Status Gizi Sebelum } & \multicolumn{2}{c}{ Jumlah } \\
\cline { 3 - 4 } & & $\mathrm{n}$ & $\%$ \\
\hline 1 & Gizi Lebih & 1 & 3 \\
2 & Gizi Baik & 28 & 80 \\
3 & Gizi Kurang & 6 & 17
\end{tabular}




\begin{tabular}{lcc}
\hline Jumlah & 35 & 100
\end{tabular}

Dari hasil tabel status gizi sebelum intervensi kelompok perlakuan didapatkan status gizi balita yang paling banyak yaitu gizi lebih 28 orang $(80 \%)$ dan paling rendah gizi lebih yaitu 1 orang (3\%).

\section{Status Gizi Sebelum Intervensi Pada Kelompok Kontrol}

Status gizi anak Baduta sebelum intervensi kelompok kontrol lebih jelasnya dapat dilihat pada Tabel 6 berikut ini.

Tabel 6. Distribusi Responden Menurut Status Gizi (BB/U) Sebelum Intervensi Pada Kelompok Kontrol

\begin{tabular}{llcc}
\hline \multirow{2}{*}{ No } & \multirow{2}{*}{ Status Gizi Sebelum } & $\mathrm{n}$ & Jumlah \\
\cline { 3 - 4 } & & 2 & $\%$ \\
\hline 1 & Gizi Lebih & 24 & 6 \\
2 & Gizi Baik & 9 & 68 \\
3 & Gizi Kurang & 35 & 26 \\
\hline Jumlah & & 900 \\
\hline
\end{tabular}

status gizi balita yang paling banyak yaitu gizi lebih 24 orang $(68 \%)$ dan paling rendah gizi lebih yaitu 2 orang (6\%).

\section{A. Status Gizi Baduta Setelah Intervensi Pada Kelompok Perlakuan}

Status gizi anak Baduta sebelum intervensi kelompok perlakuan lebih jelasnya dapat dilihat pada Tabel 7 berikut ini.

Tabel 7. Distribusi Responden Menurut Status Gizi (BB/U) Setelah Intervensi Pada Kelompok Perlakuan

\begin{tabular}{llcc}
\hline \multirow{2}{*}{ No } & \multirow{2}{*}{ Status Gizi Sebelum } & $\mathrm{n}$ & Jumlah \\
\cline { 3 - 4 } & & 1 & $\%$ \\
\hline 1 & Gizi Lebih & 30 & 3 \\
2 & Gizi Baik & 3 & 86 \\
3 & Gizi Kurang & 35 & 11 \\
\hline & Jumlah & 100 \\
\hline
\end{tabular}

Dari hasil tabel status gizi sebelum intervensi kelompok perlakuan didapatkan status gizi balita yang paling banyak yaitu gizi lebih 28 orang $(80 \%)$ dan paling rendah gizi lebih yaitu 1 orang (3\%).

\section{Status Gizi Setelah Intervensi Pada Kelompok Kontrol}

Status gizi anak Baduta setelah intervensi kelompok kontrol lebih jelasnya dapat dilihat pada Tabel 8 berikut ini.

Tabel 8. Distribusi Responden Menurut Status Gizi (BB/U) Setelah Intervensi Pada Kelompok Kontrol 


\begin{tabular}{llcc}
\hline \multirow{2}{*}{ No } & \multirow{2}{*}{ Status Gizi Sebelum } & $\mathrm{n}$ & Jumlah \\
\cline { 2 - 4 } & & 2 & $\%$ \\
\hline 1 & Gizi Lebih & 24 & 6 \\
2 & Gizi Baik & 9 & 68 \\
3 & Gizi Kurang & 35 & 26 \\
\hline Jumlah & & 350 \\
\hline
\end{tabular}

Dari hasil tabel status gizi sebelum intervensi kelompok perlakuan didapatkan status gizi balita yang paling banyak yaitu gizi lebih 24 orang $(68 \%)$ dan paling rendah gizi lebih yaitu 2 orang (6\%).

\section{Perbedaan Pengetahuan Ibu Sebelum dan Sesudah Intervensi}

Data analisis statistik perbedaan pengetahuan ibu tentang gizi sebelum dan setelah pemberian intervensi pada kelompok perlakuan seperti diuraikan pada Tabel 9 berikut ini.

Tabel 9 Perbedaan Pengetahuan Ibu Tentang Gizi Sebelum Dan Setelah Pemberian Intervensi Pada Kelompok Perlakuan

$\begin{array}{ccccc}\text { No } & \text { Pengetahuan } & \text { Rata-rata } & \mathrm{p} & \text { Keterangan } \\ \text { 1. } & \text { Pretest } & 13.6 & & \text { Signifikan } \\ \text { 2. } & \text { Postest } & 15.6 & 0,000 & \end{array}$

Sesuai hasil pada Tabel 9, nilai rata-rata pengetahuan ibu tentang gizi pada kelompok intervensi lebih tinggi pada postest yaitu dari 13,6 menjadi 15,6 . Hasil uji statistic dengan uji paired t test menunjukkan $\mathrm{p}=0,000 \mathrm{p}<\alpha(0,05)$ berarti $\mathrm{H} 0$ ditolak artinya ada perbedaan yang bermakna antara pengetahuan ibu tentang gizi sebelum dan setelah dilakukan intervensi pada kelompok perlakuan. Hasil yang sama juga dilaporkan pada penelitrian Chandradewi, dkk (2011) tentang pengaruh penyuluhan gizi terhadap pola pemberian MP-ASI, berat badan dan stautus gizi anak, bahwa ada perbedaan pola pemberian MP ASI pada anak usia $6-24$ bulan sebelum dan sesudah pemeberian penyuluhan.

\section{Perbedaan Status Gizi (Berat Badan) Baduta Sebelum dan Sesudah Intervensi}

Data analisis statistik perbedaan status gizi atau berat badan Baduta sebelum dan setelah pemberian intervensi pada kelompok perlakuan seperti diuraikan pada Tabel 10 berikut ini.

Tabel 10 Perbedaan Status Gizi (Berat Badan) Baduta Sebelum Dan Setelah Pemberian Intervensi Pada Kelompok Perlakuan

$\begin{array}{ccccc}\text { No } & \text { Berat Badan } & \text { BB }(\mathrm{Kg}) & \mathrm{p} & \text { Keterangan } \\ \text { 1. } & \text { Pretest } & 10,4 & & \text { Tidak Signifikan } \\ \text { 2. } & \text { Postest } & 10,6 & 0,514 & \end{array}$

Sesuai hasil pada Tabel 10, nilai rata-rata berat badan pada kelompok intervensi lebih tinggi pada pada postest yaitu dari $10,4 \mathrm{Kg}$ menjadi $10,6 \mathrm{Kg}$. Hasil uji statistic dengan uji paired test menunjukkan $\mathrm{p}=0,514$ atau $\mathrm{p}>\alpha(0,05)$ berarti $\mathrm{HO}$ diterima 
artinya tidak ada perbedaan yang bermakna antara berat badan Baduta sebelum dan setelah dilakukan intervensi pada kelompok perlakuan.

\section{PEMBAHASAN}

Hasil pada penelitian ini ditemukan juga dalam beberapa penelitian lain. Sarbini. D dan Rahmawaty S (2008) menemukan bahwa pelatihan terdapat peningkatan pengetahuan dan ketrampilan kader posyandu tentang cara membuat MP-ASI lokal yang berkualitas terutama dari BMC, dengan skor pengetahuannya sebelum pelatihan $68,11 \%$ (kurang) menjadi 97,74\% (baik) setelah pelatihan dan 22,22 \% peserta pelatihan mempraktekkan MP-ASI lokal. Menurut Husniyawati Y.R. dan Wulandari R.D. (2016) terdapat pengaruh antara motivasi dengan kinerja kader Posyandu di Wilayah Kerja Puskesmas Sidotopo Wetan Kota Surabaya. Mayoritas kinerja kader tergolong baik serta motivasi kader sebagian besar termasuk tinggi.

Menurut Retno S.H., Soebijanto A.A, Hadiwidjaja S. (2013) terdapat pengaruh pelatihan PMBA terhadap pengetahuan dan keterampilan konseling bidan desa tetapi tidak berpengaruh terhadap motivasi.

Menurut Septiana R, Djannah R.S.N.D., Djamil M. Pola pemberian makanan pendamping ASI di wilayah kerja Puskesmas Gedongtengen sebagian besar termasuk dalam kategori baik $(91,89 \%)$. Status gizi balita usia 6 sampai 24 bulan di wilayah kerja Puskesmas Gedongtengen sebagian besar termasuk dalam kategori normal $(77,03 \%)$. Ada hubungan yang bermakna antara pola pemberian MP-ASI dan status gizi balita usia 6-24 bulan di Puskesmas Gedongtengen Yogyakarta. nilai $P=0,043$ pada $\alpha=5 \%(0,043)$.

\section{KESIMPULAN}

Terdapat perbedaan bermakna pengetahuan ibu Baduta sebelum dan sesudah pelatihan pembuatan MP-ASI berbasis pangan lokal. Sedangakan status gizi anak Baduta sebelum dan sesudah pemberian MP-ASI berbasis pangan local tidak terdapat pebedaan. Saran sebaiknya ibu Baduta diberi pelatihan tentang cara pembuatan MPASI sehingga ibu dapat membuat sendiri makanan untuk anaknya dengan memanfaatkan pangan local yang ada di daerah masing-masing.

\section{DAFTAR PUSTAKA}

Almatsier, S (2004) Prisip Dasar Ilmu Gizi. Gramedia Pustaka Utama, Jakarta.

Arisman, (2004) Gizi dalam daur kehidupan :Buku Ajar Ilmu Gizi. Penerbit Buku Kedokteran EGC, Jakarta.

Depkes (2005b) Pedoman Pengelolaan Makanan Pendamping ASI (MP-ASI), Jakarta

Depkes R.I., 2006. Pedoman Umum Pemberian Makanan Pendamping Air Susu Ibu (MP-ASI) Lokal Tahun 2006

Depkes (2007) Keputusan Menteri Kesehatan Republik Indonesia Nomor: 224/Menkes/SK/II/2007 tentang Spesifikasi Makanan Pendamping Air Susu Ibu (MP-ASI) tanggal 26 Pebruari 2007, Jakarta

Balitbangkes, 2008. Riset Kesehatan Dasar Tahun 2007.

Balitbangkes, 2013. Riset Kesehatan Dasar Tahun 2013.

Balitbangkes, 2014. Survey Diet Total Tahun 2014

Bappenas, 2011. Rencana Aksi Nasional Pangan Dan Gizi 2011-2015. Kementerian Perencanaan Pembangunan Nasional. 
De Pee S, Diekhans J, Stallkamp G, Kiess L, Moench-Pfanner R, Martini E, et al, 2002. Breastfeeding and complementary feeding practices in Indonesia: nutrition \& health surveillance system annual report 2002. Jakarta: Helen Keller Worldwide; 2002.

DPR-RI, 2012. Undang-Undang Republik Indonesia Nomor 18 Tahun 2012 Tentang Pangan

FAO, 2010. Fats and fatty acids in human nutrition: report of an expert consultation. Rome: FAO; 2010.

Hadi, H. (2004), Beban ganda masalah gizi dan implikasinya terhadap pembangunan Nasional : Pidato Pengukuhan Guru Besar pada Fakultas Kedokteran UGM, Yogyakarta.

Husniyawati Y.R. dan Wulandari R.D. (2016). Analisis Motivasi Terhadap Kinerja Kader Posyandu Berdasarkan Teori Victor Vroom. Jurnal Administrasi Kesehatan Indonesia Volume 4 Nomor 2 Juli- Desember 2016.

Kementerian Kesehatan R.I, 2010. Permenkes R.I Nomor 1995 tahun 2010 Tentang Standar Antropometri Penilaian Status Gizi Anak

Kementerian Kesehatan R.I, 2013. Permenkes R.I Nomor 75 tahun 2013 Tentang Angka Kecekupan Gizi yang dianjurkan bagi Bangsa Indonesia

Lemeshow, S., Hosmer, D. W., Klar, J. \& Lwanga, S. K. (1997) Besar Sampel dalam Penelitian Kesehatan Yogyakarta, Gajah Mada University Press.

Lensun, C.I.J., dkk., 2013. Pemanfaatan Sagu Baruk (Arenga Microcarpa) Dengan Ubi Jalar Ungu (Ipomoea Batatas) Dalam Pembuatan Mie Basah. Skripsi Fakultas Pertanian Universitas Samratulangi Manado, 2013.

Retno S.H., Soebijanto A.A, Hadiwidjaja S. (2013). Pengaruh Pelatihan Pemberian Makan Pada Bayi dan Anak (PMBA) terhadap Pengetahuan, Keterampilan Konseling dan Motivasi Bidan Desa. Jurnal DIKESA ISSN. 2356423654 (Vol 1, No 1) (Januari, 2013) hal. 1-20, UNS.

Sarbini. D dan Rahmawaty S (2008). Jurnal WARTA, Vol .11, No. 1, Maret 2008: 82 - 8982 Fakultas IImu Kesehatan Universitas Muhammadiyah Surakarta.

Septiana R, Djannah R.S.N.D., Djamil M. Pelatihan Pembuatan MP-ASI Lokal dengan Bahan Dasar BMC (Bahan Makanan Campuran) Untuk Balita Pada Kader Posyandu di Wilayah Kerja :Puskesmas Stabelan Surakarta. Jurnal KES MAS Vol. 4.No. 2, JUNI $2010: 76-143$. 